\title{
Analisis Perlakuan Akuntansi pada Kas Kecil PT. Kallista Alam Kantor Medan
}

\begin{abstract}
Author:
Putri Wulandari ${ }^{1}$

Yus Epi ${ }^{2}$

Afiliation:

Politeknik Ganesha ${ }^{1,2}$

Corresponding email

yus_epi20@yahoo.co.id

Histori Naskah:

Submit: 07-06-2021

Accepted: 08-07-2021

Published: 08-07-2021

Abstrak: Tujuan dari penelitian ini adalah untuk mengetahui bagaimana perlakuan akuntansi pada kas kecil ang diterapkan PT.Kallista Alam Kantor Medan.Jenis data yang digunakan dalam penelitian ini adalah data primer dan data sekunder yang diperoleh dari objek penelitian, antara lain : Data Kas Kecil Perusahaan, gambaran umum perusahaan dan data pendukung lainnya yang terkait dalam penelitian. Untuk membahas dan menganalisa masalah yaitu digunakan metode deskriptif dimana data yang dikumpulkan, disusun, diinterpretasikan dan dianalisis sehingga menjadi sebuah keterangan yang lengkap bagi pemecahan masalah yang dihadapi. PT.Kallista Alam kantor Medan dalam perlakuan akuntansi pada kas kecil yang menggunakan metode dana tidak tetap (Fluctuation Fund System). Dimana metode Fluctuation Fund System merupakan metode yang digunakan dalam pngelolaan kas kecil yang saldo rekeningnya tidak tetap dan tergantung pada besar kecilnya pengeluaran yang terjadi untuk periode tertentu. Dalam melakukan pengelolaan kas kecil dimana setiap pengeluaran kas kecil dicatat atau dijurnal pada tanggal transaksi tersebut. Hasil penelitian menunjukkan bahwa perlakuan akuntansi pada kas kecil diPT.Kallista Alam menggunakan metode dana tidak tetap (Fluctuation Fund System).
\end{abstract}

Kata kunci: Kas Kecil. Metode Dana Tidak Tetap

\section{Pendahuluan}

Penerapan akuntansi dalam sebuah perusahaan dapat mengoptimalkan biaya operasional yang dikeluarkan.Salah satu penerapan akuntansi yang digunakan oleh perusahaan adalah kas kecil (Petty Cash). Dalam pengelolaan kas kecil perusahaan seharusnya membentuk dana kas kecil yang rutin, yaitu dana kas kecil yang disediakan dalam jumlah yang sama dan dilakukan perperiode tertentu, bisa dilakukan mingguan atau bulanan. Penggunaan metode tetap dalam pengelolaan kas kecil pada perusahaan tersebut dipegang oleh seorang kasir atau admin kas kecil.

Kas kecil merupakan sejumlah dana yang dibentuk khusus untuk pengeluaran yang bersifat harus didahulukan pendanaanya/pembayaranya dan relatif kecil jumlahnya.Setiap pengeluaran uang dibuktikan dengan bukti pengeluaran kas kecil. Kelengkapan dokumen pada dana kas kecil menunjukkan bahwa pengelolaan kas kecil sudah berjalan dengan baik. Apabila pengelolaan kas kecil tidak dilakukan dengan baik maka akan menimbulkan dampak pada laporan keuangan perusahaan. Penyelewengan pada kas kecil dapat terjadi apabila pengelolaan tidak dijalankan sesuai dengan standart akuntansi kas kecil.

Berdasarkan penelitian terdahulu dari Sri Winarni (2015) yang berjudul Analisis Perlakuan Akuntansi Kas Kecil Pada PT.Andromeda Graha Palembang, menyatakan bahwa untuk mendapatkan hasil yang efektif dari pelaksanaan kas kecil, maka pengelolaan kas kecil pada perusahaan harus dilakukan dengan baik dan benar. Seluruh dokumen yang digunakan saat pengambilan dana kas kecil maupun saat pengembalian kas kecil harus lengkap dan telah diperiksa keaslianya agar tidak terjadi perselisihan dalam pengelolaan kas kecil. 
PT.Kallista Alam sebagai perusahaan perkebunan kelapa sawit dituntut untuk selalu professional dalam menjalankan usahanya, baik pada saat pengelolaan internal perusahaan maupun dalam hubungan kerja kepada vendor yang ada. PT.Kallista Alam dalam menjalankan usahanya selalu membutuhkan kas kecil, Kas kecil diperlukan baik untuk membiayai operasi perusahaan sehari-hari yang relatif kecil dan dibutuhkan cepat dalam pembayaran nya.

Perumusan masalah yang akan dibahas dalam tugas akhir ini adalah : "Bagaimanakah perlakuan akuntansi pada pengelolaan kas kecil PT.Kallista Alam Kantor Pusat Medan’”

Penelitian ini diambil menggunakan data kas kecil periode Oktober s/d Desember tahun 2020 pada PT.Kallista Alam Kantor Pusat Medan, tujuan utama dalam melaksanakan penelitian ini adalah untuk mengetahui bagaimanakah perlakuan akuntansi terhadap kas kecil pada PT.Kallista Alam Kantor Pusat Medan.

\section{Studi Literatur \\ Pengertian Kas}

Kas merupakan sesuatu yang dapat digunakan dalam melakukan sebuah pembayaran. Kas juga dapat berupa rekening giro dibank, dan uang kas yang ada diperusahaan. Bisanya untuk uang kas yang ada diperusahaan, perusahaan dapat membentuk kas kecil (Petty cash) hal itu dikemukakan oleh Rizal Effendi (2015 :191)[6] Sedangkan jika menurut Agoes (2016:166), kas adalah sebuah asset atau harta lancar bagi sebuah perusahaab, harta lancar yang sangat menarik dan mudah untuk diselewengkan bagi pihak yang menginginkannya [7]

Menurut Samryn (2015:31), Uang logam, uang kertas, cek dan money orders merupakan salah satu asset perusahaan yang tegolong dalam pengertian kas. Termasuk uang yang ada ditangan atau dalam bentuk deposito dibank atau lembaga deposito lainnya yang menjadi unsur kas. [8]

Menurut pengertian diatas, dapat disimpulkan bahwakas adalah sebuah alat pembayaran yang siap dan bebas dipergunakan untuk membiayai kegiatan umum perusahaan. Kas terdiri dari saldo kas (cash on hand) dan rekening giro yang ada pada perusahaan.

\section{Jenis-Jenis Kas}

Menurut Mulyadi (2016) mengatakan bahwa ada tiga jenis kas yaitu:

1. Petty Cash (Kas Kecil)

Kas kecil merupakan salah satu kas dalam bentuk uang tunai yang telah dipersiapkan oleh perusahaan dalam melakukan pembayaran berbagai pengeluaran yang bernilai relative kecil dan jika menggunakan cek tidaklah ekonomis dan efektif.

2. (Cash in Bank) Kas di Bank

Uang yang disimpan oleh perusahaan kedalam rekening yang ada dibank yang berjumlah relative besar dan sangat membutuhkan keamanan yang lebih baik dari pada biasanya merupakan arti dari kas di ban. Dalam hal ini, Kas yang ada diBank selalu membutuhkan rekening Koran karena saling berhubungan satu dengan yang lainnya.

3. Pelaporan Kas

Pelaporan kas keuangan dapat dilakukan secara langsung bagi pemegang kas keuangan. Namun pada pelaksanaanya dapat terjadi beberapa masalah, berikut adalah beberapa penyebab permasalahan yang ada dalam pelaporan kas keuangan:

a. Setara kas atau dapat juga disebut dengan Cash Equivalents yang merupakan sekelompok harta perusahaan yang penggunaan atau jangka waktu pemakaiannya kurang dari tiga bulan. 
b. Kas yang dipisahkan khusus untuk membayar kewajiban yang nilainya cukup besar dan dimasa yang akan datang atau dapat juga disebut dengan Restricated Cash

c. Rekening negative yang terjadi karena adanua nasabah yang menulis cek yang melebihi jumlah dana yang ada pada rekeningnya dan dianggap sebagai utang sehingga dapat dilaporkan sebagai sesuatu seperti ekspansi kredit dapa juga disebut dengan Bank Overdrafts [9]

\section{Pengertian Kas Kecil}

Pengertian kas kecil menurut Soemarso (2019) ialah kas kecil merupakan sebuah nominal uang yang disisihkan yang berjumlah tidak besar dan memiliki fungsi memberikan pelayanan perusahaan dan pengeluaran yangn telah dilakukan bank.[11]

Menurut Dwi Suratni (2016) Kas kecil merupakan sejumah uang kas atau uang tunai untuk membayar pengeluaran yang berjumlah relative kecil yang disediakan oleh perusahaan dan tidak ekonomis apabila dibayarkan dengan mengunakan cek. Pembelian perangko, materai, pembayaran rekening listrik,telepon dan lainnya pengeluaran yang dapat menggunakan kas kecil. Pemegang dana kas kecil akan bertanggung jawab penuh terhadap pengeluaran dan penggunaan kas kecil diperiode tertentu. [12]

Sedangkan menurut Rudianto (2018:188) kas kecil merupakan sejumlah uang berbentuk tunai yang telah disediakan oleh perusahaan untuk membayar tagihan yang jumlahnya relative kecil. .[13]

Berdasarkan pengertian di atas dapat disimpulkan bahwa kas kecil merupakan sejumlah uang tunai yang diambil dari kas perusahaan yang digunakan untuk membayar pengeluaran yang tergolong kecil dan bersifat langsung dibayar atau langsung dibeli.

\section{Karakteristik Kas Kecil}

Kas kecil memliki beberapa karakteristik menurut Sandi (2017),diantaranya:

a. Pihak manajemen biasanya membatasi jumlah kas kecil sesuai dengan permintaan dan kebutuhan perusahaan. Jika dilihat dari tingkat operasionalnya jumlah kas kecil tiap perusahaan berbeda-beda.

b. Kas kecil digunakan untuk membiayai transaksi atau tagihan yang berjumlah kecil . Kas kecil memiliki tujuan untuk mendanai transaksi yang bersifat rutin yang dalam jumlah kecil. Besar kecinya dana kas kecil suatu perusahaan ditentukan oleh manajemen perusahaan. [14]

\section{Fungsi Kas Kecil}

Fungsi kas kecil Menurut Sandi (2017) Adapun Fungsi kas kecil secara rinci bisa dijabarkan seperti berikut ini:

- Untuk membayar pengeluaran-pengeluaran tagihan perusahaan uang jumlah nominalnya relatif kecil.

- Sebagai dana talangan dalam membayarkan tagihan/pengeluaran yang sifatnya mendadak atau harus segera dibayarkan.

- Kas kecil sebagai dana langsung/dana tunai yang digunakan untuk jenis-jnnis pembayaran yang apabila menggunakan cek atau giro menjadi tidak praktis dan ekonomis.

- Kas kecil untuk mempercepat proses pembayaran transaksitagihan yang tidak praktis jika menggunakan lampiran keuangn yang perlu ditandatanganin oleh direktur terlebih dahulu karena akan memakan waktu yang lama dan harus melalui proses yang panjang.[15]

\section{Metode dan Dokumen dalam Kas Kecil}

Dalam pengelolaan dana kas kecil memiliki dua metode menurut Mulyadi (2016:425). Adapun kedua metode tersebut ialah metode dana tetap dan dana tidak tetap. Dibawah ini merupakan penjelasan dari kedua metode dana kas kecil, 
a. Metode dana tetap (Imprest fund system) .

Metode dana tetap merupakan suatu metode pengendalian dan pengisian dana kas kecil dimana dari waktu ke waktu jumlah pengisian dan kas kecil selalu sama dengan jumlah yang telah dikeluarkan. Penggunaan dana kas kecil yang menggunakan metedo tetap (Impest fund system) ini tidaklah memerlukan pencatatan atau penjurnalan atas setiap transaksi yang dilakukan. Pada saat pengisian kembali dana kas kecil, dana yang diisi berjumlah sama dengan jumlah seluruh pengeluaran yang telah dilakukan berdasarkan bukti resmi yang dimiliki. Dalam metode dana tetapp ini memiliki prosedur dalam penyelenggaraan danakas kecil yang dilakukan, di bawah ini ada beberapa prosedur yang harus dilakukan, yaiu:

1. Pembentukan awal atau pengisian dana kas kecil dilakukan dengan menggunakan cek perusahaan dan dicatat dengan cara mendebit rekening dana kas kecil. Saldo dana kas kecil diisi dengan jumlah yang sama dan tidak boleh berubah-ubah sesuai ketetapan yang telah ditentukan oleh perusahaan sebelumnya, kecuali apabila saldo yang telah ditetapkan telah dinaikan atau diturunkan sesuai dengan ketentuan peraturan perusahaan.

2. Pengeluaran atau pemakaian yang menggunakan dana kas kecil tidak dicatat dalam jurnal, sehingg tidak ada yang mengkredit dana kas kecil. Pengarsipan bukti-bukti pengeluaran dana kas kecil dikumpulkan dalam map khusus dana kas kecil yang diselenggarakan oleh pemegang dan kas kecil.

3. Hal selanjutnya ialah pengisian kebali dana kas kecil yang dilakukan pemegang dana kas kecil dengan membuat permintaan saldo dana kas kecil sejumlah rupiah yang telah dicatumkan dalam kumpulan bukti-bukti pengeluaran kas kecil. Pengisian kembali dana ks kecil dilakukan dengan menggunakan cek perusahaaan, keudian mendebit rekeninng-rekening biaya dan mengkredit rekening kas perusahaan.

b. Metode dana tidak tetap (Fluctuation fund system)

Metode dana tidak tetap adalah suatu pengendalian dan pencatatan dana kas kecil, dimana jumlah kas kecil selalu berubah-ubah dan tidak tetap. Karena pengisian kembali dana kas kecil akan berubah-ubah sesuai kebutuhan perusahaan. Setiap pemakaian dana kas kecil akan selalu dicatat atau dilakukan penjurnalan berdasarkan bukti transaksi yang ada pada pemegang dana kas kecil Dalam sistem fluktuasi penyelenggaraan dana kas kecil dilakukan dengan beberapa prosedur yang akan dijelaskan sebagai berikut:

1. Pembentukan dana kas kecil akan dicatat dengan cara mendebit rekening dari dana kas kecil perusahaaan.

2. Pemakaian kas kecil atau pengeluaran dana kas kecil dicatat atau dijurnal dengan mengkredit rekening dana kas kecil sehingga setiap saldo rekening akan berubah atau berfluktuasi.

3. Pengisian kembali dana kas kecil dilakukan dengan menggunakan cek perusahaan sesuai dengan keperluan perusahaan dan diatat dengan cara mendebit rekening dana kas kecil dang mengkredit dana kas perusahaan. Pada metode dana tidak tetap ini saldo perusahaan akan berfluktuasi dari waktu ke waktu tergantung keperluan perusahaan. [16]

Menurut Risal Efendi (2015:193) Pada pengelolaam dana kas kecil terdapat dua metode pad kas kecil, yaitu metode dana tidak tetap dan metode dana berubah-ubah dapat silihat pada table berikut.[17]

Tabel 1.1 Perbedaan Antara Metode Dana Tetap dan Dana Berubah

\begin{tabular}{|c|c|c|c|}
\hline No & Uraian & Metode Dana Tetap & etode Dana Berubah \\
\hline & Pada saat pengisian kas kecil & $\begin{array}{ll}\text { (D) Kas Kecil } & \mathrm{xxx} \\
\text { (K)Kas/Bank } & \mathrm{xxx}\end{array}$ & $\begin{array}{ll}\text { (D)Kas Kecil } & \mathrm{xxx} \\
\text { (K)Kas/Bank } & \mathrm{xxx}\end{array}$ \\
\hline
\end{tabular}


Jebma (Jurnal Ekonomi Bisnis, Manajemen dan Akuntansi)

Volume : 1 | Nomor 1 | Maret 2021 | E-ISSN : 2797-7161 |DOI: 10.47709 /jebma.v1n1.971

\begin{tabular}{|l|l|l|l|}
\hline 2 & Pada Saat Terjadi Pengeluaran & Tidak dilakukan penjurnalan (No entry) & $\begin{array}{l}\text { Biaya xxx } \\
\text { (K) Kas Kecil xxx }\end{array}$ \\
\hline & $\begin{array}{l}\text { Pada Saat Pertanggung Jawaban } \\
\text { atau Pengisian Kembali }\end{array}$ & $\begin{array}{l}\text { (D)NamaPengeluaran } \\
\text { (K)Kas } \quad \mathrm{xxx}\end{array}$ & $\begin{array}{l}\text { (D) Kas Kecil xxx } \\
\text { (K)Kas/Bank xxx }\end{array}$ \\
\hline
\end{tabular}

Dokumen yang digunakan dalam Sistem Kas Kecil menurut Mulyadi (2016:446) yaitu :

a. Bukti kas keluar.

Bukti kas keluar berfungsi sebagai suatu perintah untuk pengeluaran kas dari fungsi akuntansi kas dengan jumlah yang sebesar yang telah dicatumkan pada dokumen tersebut.Pada system dana kas kecil, dokumen sangatlah diperlukan pada pembentukan dana kas kecil dan saat pengisian kembali kas kecil.

b. Cek

Cek merupakan salat satu sarana untuk menarik uang perusahaan didalam rekening giro. Cek juga berfungsi sebagai alat dalam melakukan pembayaran atau transaksi di perusahaan.

c. Permintaan pengeluaran dana kas kecil.

Pada permintaan pengeluaran dana kas kecil harus melampirkan dokumen permintaan dana kas kecil kepada pemegang kas kecil oleh pihak yang membutuhkan dana kas kecil. Sedangkan bagi pemegang dana kas kecil dokumen ini sangatlah berfungsi sebagai bukti bahwa telah dikeluarkannya kas kecil dibagian keuangan. Selanjutnya dokumen akan diarsipkan oleh pemegang dana kas kecil.

d. Bukti Pengeluaran Kas Kecil

Bukti pengeluaran kas kecil biasanya dibuat oleh pemegang dana kas kecil untuk mempertanggung jawabkan pemakaian dana kas kecil perusahaan. Dokumen ini dilampirkan dengan bukti-bukti pengeluaran dana kas kecil kepada admin pemegang dank as kecil perusahaan.

e. Permintaan Pengisian Kembali

Pada permintaan pengisian kembali dana kas kecil, pemegang kas kecil memerlukan seluruh dokumen lengkap bukti pemakaian dana kas kecil yang telah terpakai, kemudian pemegang kas kecil harus membuat dokumen pengisian kembali dana kas kecil perusahaan yang ditujukan pada Direksi Utama perusahaan.[18]

\section{Fungsi Kas Kecil}

Adapun fungsi kas kecil yang terkait menurut Mulyadi (2016:446):

a. Fungsi kas

Fungsi kas bertanggung jawab dalam mengisi cek perusahaan, kemudian memintakan otoritas cek dan menyerahkan cek kepada pemegang dana kas kecil yang ada diperusahaan saat pembentukan dan juga pada saat pengisian kembali dana kas kecil perusahaan.

b. Fungsi akuntansi

Fungsi akuntansi ini bertanggung jawab atas segala pencatatan pengelluaran dana kas kecil yang menyangkut seluruh biaya dan juga persediaan., Pembentukan dana kas kecil dan juga pencatatan transaksi pemakaian dana kas kecil dalam jurnal pengeluaran dana kas kecil dan pembuatan BKK yang memberikan otorisasi kepada fungsi kas dalam menggunakan cek sebesar yang terlampirkan dan tercantum didalam dokumen.

c. Fungsi pemegang kas kecil

Fungsi pemegang kas kecil ini bertanggung jawab atas penyimpanan saldo kas kecil, sesuai dengan otorisasi dari pihak yang berwenang pengeluaran dana kas kecil dikeluarkan oleh pejabat tertentu yang ditunjuk dan permintaan kembali dana kas kecil.

d. Fungsi yang memerlukan pembayaran via tunai(Cash) 
Fungsi yang memerlukan pembayaran via tunai ini mengajukan pemintaan untuk melakukan pembayaran tunai yang menggunakan dana kas kecil untuk melakukan pembayaramn dan sebagainya.

e. Fungsi pemeriksaan internal

Fungsi pemeriksaan internal ini bertanggung jawab atas perhitungan dana kas kecil secara periodik dan pencocokan hasil perhitungan dengan pencatatan kas. [19]

\section{Penelitian Terdahulu}

Table 1.4 Penelitian Terdahulu

\begin{tabular}{|c|c|c|}
\hline $\begin{array}{c}\text { Nama } \\
\text { peneliti }\end{array}$ & Judul peneliti & Hasil penelitian \\
\hline $\begin{array}{l}\text { Dwi } \\
\text { Suratni } \\
2016\end{array}$ & $\begin{array}{l}\text { Perlakuan Akkuntansi Pada } \\
\text { Kas Kecil Pada Perusahaan } \\
\text { Sample }\end{array}$ & $\begin{array}{l}\text { Pengelolaan kas kecil pada perusahan sampel masih } \\
\text { tergolong kurang baik, adanya kekurangan dokumen yang } \\
\text { digunakan seperti permintaan pengeluaran kas kecil. } \\
\text { Kurangnya perhatian bagi pihak perusahaan dengan tidak } \\
\text { adanya dokumen permintaan pengeluaran kas kecil yang } \\
\text { digunakan, mengakibatkan pengeluaran uang yang keluar } \\
\text { tidak adanya bukti pengeluaran uang yang terlampir oleh } \\
\text { pembawa uang, sehingga dengan mudahnya dilakukan } \\
\text { penipuan terhadap uang yang dibawa.Belum efektifnya } \\
\text { pengelolaan kas kecil pada perusahaan sampel }\end{array}$ \\
\hline $\begin{array}{l}\text { Sri } \\
\text { Winarni } \\
2015\end{array}$ & $\begin{array}{l}\text { Analisis Perlskusn Akuntansi } \\
\text { Kas Kecil Pada } \\
\text { PT.Andromeda Graha } \\
\text { Palembang }\end{array}$ & $\begin{array}{l}\text { Berdasarkan penelitian PT. Andromeda Graha tidak } \\
\text { menentukan batas saldo minimum kas kecil. Sehingga } \\
\text { terjadinya kekosongan pada kas kecil. PT. Andromeda Graha } \\
\text { juga tidak melakukan pemisahaan dalam penggunaan kas } \\
\text { kecil. Padahal dengan adanya pemisahaan beban dalam } \\
\text { pengelolahannya, jumlah kas kecil tidak begitu besar. }\end{array}$ \\
\hline $\begin{array}{l}\text { Putri } \\
\text { Indira } \\
2018\end{array}$ & $\begin{array}{l}\text { Analisis Pengendalian } \\
\text { Internal Kas Kecil Pada } \\
\text { PerusahaanDaerah Air } \\
\text { Minum (PDAM) Kabupaten } \\
\text { Gowa }\end{array}$ & $\begin{array}{l}\text { sistem pengendalian internal kas kecil sudah berjalan dengan } \\
\text { baik. Hal ini dapat dilihat dari metode dana kas kecil yang } \\
\text { diterapkan telah sesuai dengan metode dana kas kecil selain } \\
\text { itu pengendalian internal yang diterapkan telah sesuai } \\
\text { dengan komponen pengendalian internal COSO, kemudian } \\
\text { dilihat dari pengendalian internal kas kecil telah sesuai } \\
\text { dengan prinsip-prinsip pengendalian internal }\end{array}$ \\
\hline
\end{tabular}

\section{Metode Penelitian}

\section{Kerangka Konseptual}

PT.Kallista Alam dalam melakukan kegiatan usahanya selalu mengarah pada pencapaian tujuan yang telah ditetapkan, Oleh karena itu perusahaan harus selalu dimotivasi untuk melaksanakan kegiatannya secara bertanggung jawab dan terarah. Salah satunya ialah pengelolaan kas kecil pada PT. Kalllista Alam. Pengelolaan kas kecil merupakan masalah yang serius, hal ini terutama menyangkut kemungkinan terjadinya kesalahan pencatatan. Kesalahan pencatatan pengeluaran kas kecil yang mengakibatkan keterlambatan dalam pembayaran membuat hal itu menjadi masalah yang kritis dan serius. 


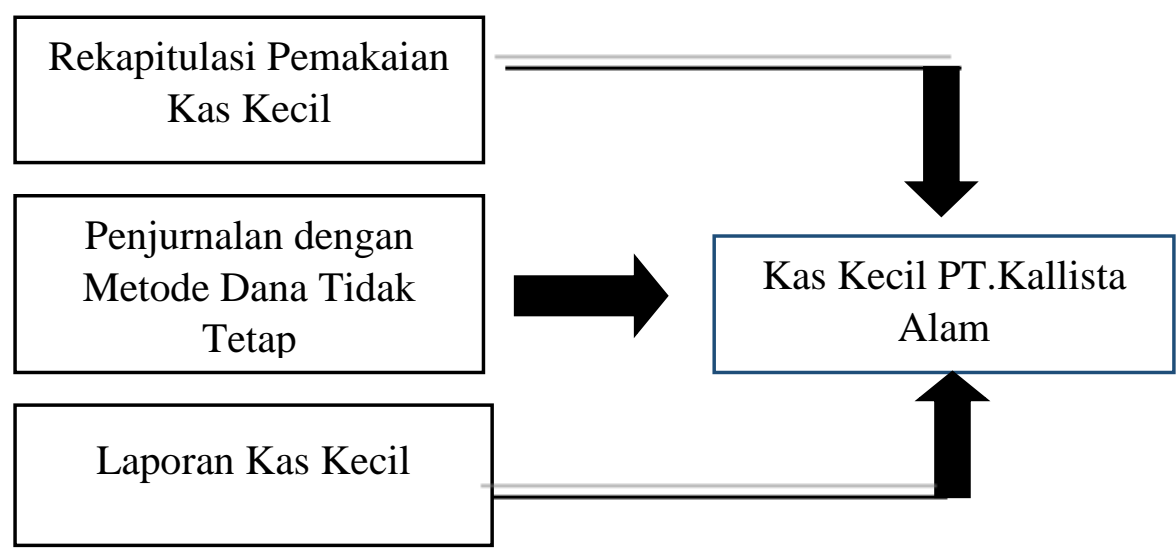

Gambar 1.3 Kerangka Konseptual

Maka dari itu diperlukanya rekapitulasi pemakaian dana kas kecil agar pemegang kas dapat memonitoring pengeluaran kas maupun pengisian kembali dana kas kecil. Untuk menghindari kesalahan dalam pengelolaan kas kecil maka pihak yang terkait dalam pengambilan kas kecil harus menjurnal kas kecil dengan metode dana tidak tetap dan memiliki dokumen yang lengkap untuk menghindari perselisihan dan sangat dibutuhkan bukti pengeluaran dana kas kecil yang ditandatanganin oleh pihak yang terkait dalam pengambilan dana, untuk mencegah terjadinya kesalahpahaman atas pendanaan yang telah dikeluarkan dari kas kecil. Maka, dari unsur - unsur permasalahan diatas diperlukan tindak lanjut yang lebih menjamin ke arah kinerja yang diharapkan lebih teliti untuk mengerjakannya, agar tidak ada masalah - masalah yang diinginkan.

\section{Hasil}

\section{Deskripsi Objek Penelitian}

Dana kas kecil pada PT.Kallista Alam di bentuk di departemen Keuangan PT. Kallista Alam. Pengelolahan dana kas kecil dipegang oleh admin bagian keuangan. Kas kecil pada PT.Kallista Alam merupakan suatu dana yang disiapkan secara rutin untuk membiayai tagihan atau pembayaran yang bersifat harus segera dibayarkan dan berjumlah relatif kecil (kurang dari Rp10.000.000,- menurut PT.Kallista Alam). Contoh biaya yang dapat didanai oleh kas kecil seperti pembelian ATK yang dibutuhkan secepatnya, pembayaran upah cabut rumput, upah service AC, upah pengantaran barang, pembelian alat-alat /sparepart (dalam hal ini yang mendesak dan sangat dibutuhkan dalam waktu secepatnya), pembayaran invoce dalam jumlah yang kecil, dan pembayaran yang mendesak saat Direksi tidak ada ditempat, Pengambilan pribadi Direksi dan lainnya.

Sesuai dengan permasalahan sebelumnya yang telah dijelaskan secara teoritis mengenai perlakuan akuntansi, serta gambaran umum dari perusahaan yang diteliti, maka bab ini akan dijelaskan hasil penelitian mengenai perlakuan akuntansi pada kas kecil PT.Kallista Alam Kantor Medan. Untuk memudahkan pembahasan maka analisis dan evaluasi yang akan difokuskan pada penjurnalan kas kecil dan metode tidak tetap yang digunakan.

Pencatatan dana kas kecil pada PT.Kallista Alam masih manual dengan mencatat pengeluaran kas kecil dibuku tulis dan belum terkomputerisasi. Penjurnalan pun belum pernah dilakukan selama ini, serta pencatatan dana kas kecil dengan metode tidak tetap (Fluctuating Fund System) belum dilakukan dengan baik. Sehingga administrasi data kas kecil dibagian keuangan masih kurang baik dan belum efektif. 


\section{Deskripsi Data Penelitian}

PT.Kallista Alam kantor Medan membuat pencatatan pengeluaran dana kas kecil secara manual untuk periode Oktober, November dan Desember 2020. Pengeluaran dana kas kecil yang baik harus disertai dengan bukti yang resmi seperti invoice, kwitansi, atau lembar permohonan dana yang dilampirkan pada saat pemohon meminta dana dari bagian kas kecil keuangan, kemudian akan dicatat ke buku tulis oleh pemegang dana kas kecil. Pencatatan dilakukan pada saat bukti telah diterima, kemudian dana diserahkan kepada pemohon, lalu lembar bukti pengeluaran dana kas kecil ditandatangani oleh pemohon . Pencatatan manual Pengeluaran dana kas kecil bulan Oktober November dan Desember 2020 (terlampir)

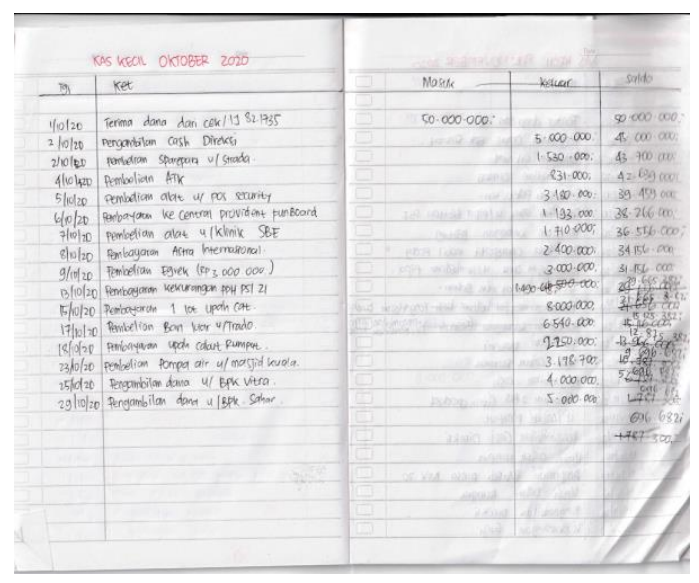

Gambar 1.4 Contoh Pencatatan Manual Kas Kecil Per. Okt'2002

\section{Pembahasan}

Dari informasi yang telah berhasil penulis kumpulkan, maka untuk menyiapkan pembuatan kas kecil PT.KallistaAlam Kantor Medan ,dimulai dengan beberapa alat pendukung. Alat pendukung yang digunakan dalam proses pembuatan kas kecil, pengeluaran dana kas kecil, hingga pengisian kembali dana kas kecil:

1. Alat tulis kantor pendukung,seperti:

a. Buku tulis untuk pencatatan dana kas kecil

b. Pulpen warna hitam dan warna merah

c. Penggaris

d. Pensil

e. Stick Notes

f. Stabilo

g. Paper Clip

h. Binder Clip

2. Aplikasi Perangkat Lunak

Software yang digunakan adalah Microsoft Excel 2013 yang telah diisi dengan format pengisian dana kas kecil

\section{Langkah -Langkah Menyelesaikan Masalah}

Hal- hal yang perlu dilakukan dalam menyelesaikan masalah pembuatan dana kas kecil adalah sebagai berikut:

1. Membuat Permohonan Dana Kas Kecil

Langkah awal dalam membuat dana kas kecil diperusahaan adalah membuatsurat permohonan dana kaskecil yang ditujukan langsung oleh Direksi Utama PT.Kallista Alam. Surat permohonan ini 
dibuat sebagai bukti lampiran dan berkas untuk pembentukan dana kas kecil. Apabila surat permohonan sudah diterima dan disetujui direksi kemudian akan dilanjutkan dengan membuat permintaan pengeluaran dana (PPD) dibagian keuangan.

2. Membuat Permintaan Dana (PPD)

Dalam mengisi blangko PPD harus mencatumkan lampiran persetujuan dari Direksi dengan jumlah uang yang telah disetujui Direksi langsung. Kemudian membuat cek dan mencairkan cek di bank. Lalu menyimpan uang yang telah dicairakan ke dalam brangkas di bagian keuangan.

3. Mencatat Pengeluaran Dana Kas Kecil

Yang harus dilakukan saat ada permintaan pengeluaran dana kas kecil dar ipihak lain adalah, mencatat seluruh engeluaran yang ada, dan menerima bukti baik berupa kwitansi, invoice maupun yang lainnya sebagai bentuk bukti pengeluaran dana kas kecil di bagian keuangan.

4. Mengisi Kembali Dana Kas Kecil

Apabila kas kecil sudah menunjukan nominal angka yang sedikit (dibawahRp 500.000,-) maka pemegang kas kecil harus melakukan pengisian kas kecil kembali dengan syarat membuat lembar pertanggung jawaban (LPG) dan menyerahkannya kepada Direksi beserta sisa uang yang ada.

\section{Pembentukan Dana Kas Kecil}

Dana kas kecil merupakan dana yang dikeluarkan untuk membiayai keperluan-keperluan yang bersifat harus segera dibayar (Mendesak) dan bernilai relative kecil sesuai ketentuan perusahaan. Pembuatan Permohonan dana kas kecil biasanya ditujukan langsung oleh Direksi Utama Perusahaan.

\section{a. Membuat Surat Permohonan Pembentukan Dana Kas Kecil}

Dana kas kecil dibentuk karena banyaknya permintaan yang ditujukan pada bagian keuangan perusahaan, agar dapat membayarkan tagihan secara tunai dan dalam waktu yang cepat, karna pada umumnya jika ingin dibayarkan suatu tagihan maka harus melewati proses yang panjang, sehingga hal ini banyak dikeluhkan oleh bagian lain dalam perusahaan.Permohonan pembentukan dana kas kecil dibuat oleh pemegang dana kas kecil apabila saldo dana kas kecil tinggal sedikit.

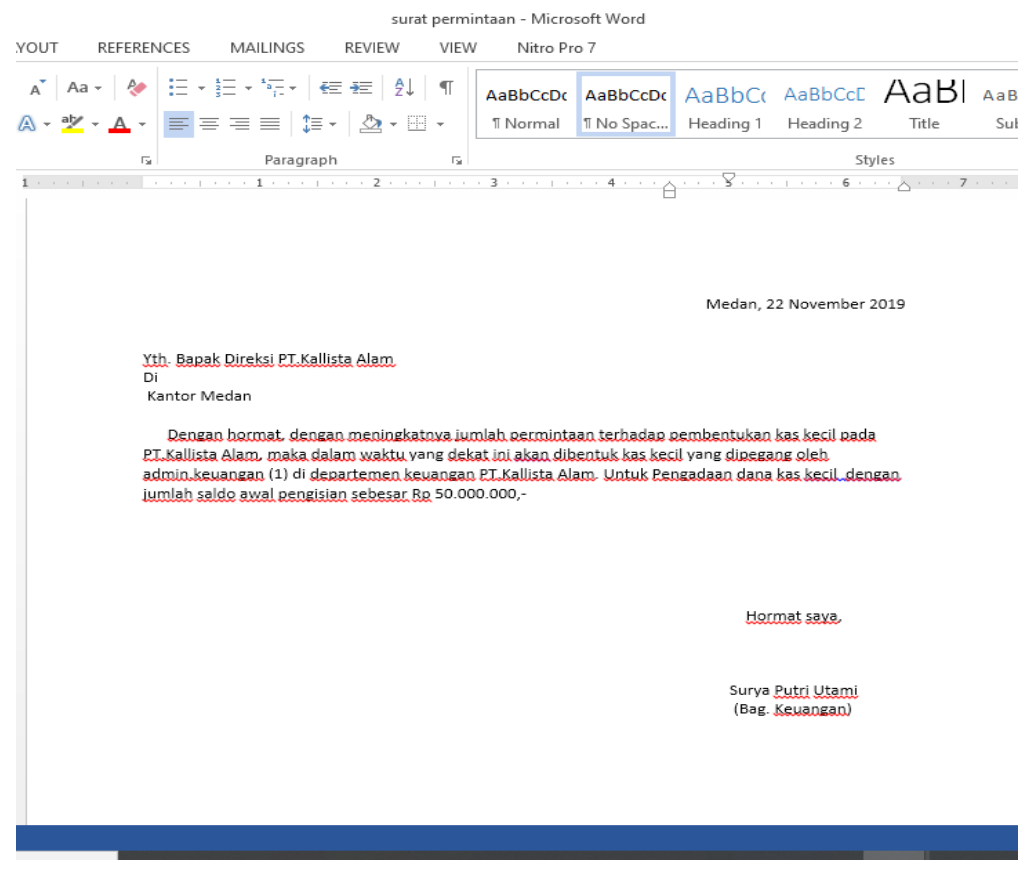

Gambar 1.5 PermohonanPembuatan Dana Kas Kecil 


\section{PembuatanPermintaanPengeluaran Dana (PPD)}

Setelah surat permohonan disetujui oleh Direksi Utama, maka bagian keuangan akan membuat PPD dan mengisi dengan nominal yang telah disetujui. Langkah yang dilakukan dalam membuat PPD adalah sebagai berikut:

1. Buka Folder PPD 2020

2. Pilih PPD Desember 2020

3. Pada blangko PPD isi no PPD ( contoh : Ka-12.170/2020)

4. Kemudian isi Keterangan Pada PPD (Contoh :Pinjaman Sementara Sdri. Surya PutriUtami u/ Kas Kecil Kantor Medan)

5. Kemudian Isi nominalnya (Contoh : Rp 50.000.000,-)

6. Kemudian Klick Vouch padaB langko, dana kas muncul tampilan seperti yang ada dibawah ini.

7. Kemudian Print PPD

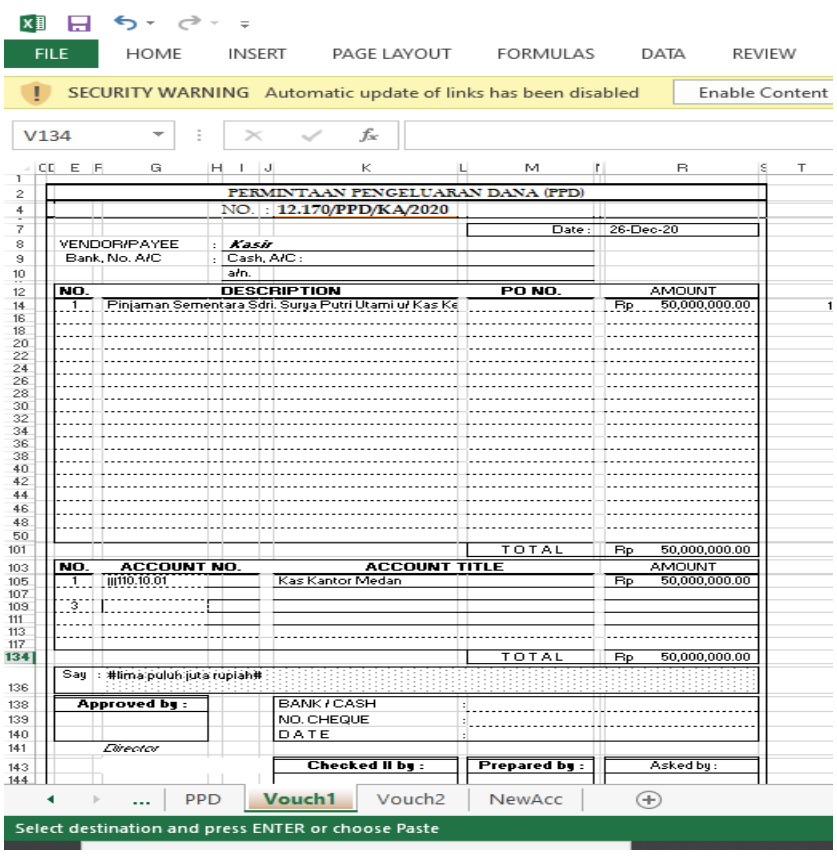

Gambar 1.6 Blangko PPD danaKas Kecil

\section{Pembuatan Cek}

Apabila permintaan pengeluaran dana telah dibuat, maka langkah selanjutnya yang akan diambil adalah membuat cek. Cek merupakansuatu suratperintah yang tidak bersyarat kepada bank untuk membayar sejumlah uang tertentu saat waktu surat demikian diserahkan kepada bank, lalu ditandatangani oleh pihak yang menjadi nasabah suatu bank serta memiliki simpanan pada bank tersebut dalam bentuk giro.

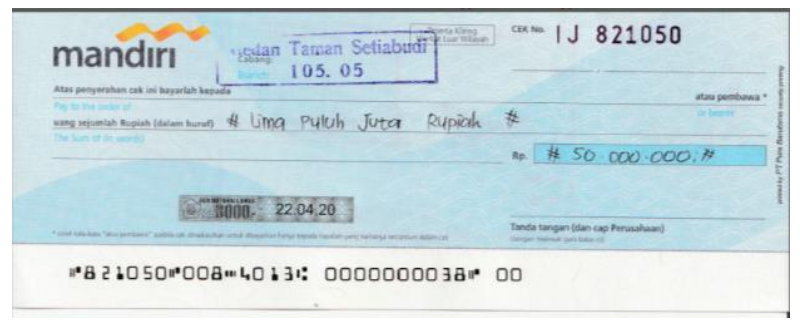

Gambar 1.7 Cek Dana Kas Kecil 


\section{Pencairan Dana Cek}

Setelah PPD di Print kemudian isi cek dengan jumlah yang ada, kemudian cek akan ditandatangani dan distempel oleh Direktur utama. Setelah cek ditandatangani dan distempel maka cek akan dimasukan ke bagian kasir. Kemudian cek akan dicairkan dengan dibawa ke bank. Setelah cek dicairkan maka akan diserahkan pada admin pemegang kas kecil keuangan. Saat penyerahan uang harus menggunakan bukti resmi dan ditanda tanganin oleh pemegang dana kas kecil.

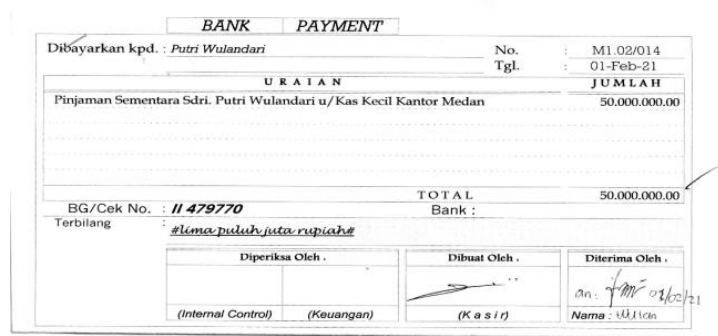

Gambar 1.8 MKas Bag.Kasir

\section{Bukti Pengeluaran Dana Kas Kecil}

Dana kas kecil dapat dikeluarkan untuk mendanai tagihan apa saja dengan syarat harus memenuhi standart pembayaran menggunakan kas kecil PT.Kallisa Alam. Apabila berkas belum lengkap maka pihak yang membutuhkan dana kas kecil harus melampirkan kwitansi sebagai bukti pertanggung jawaban pengambilan dana kas kecil.

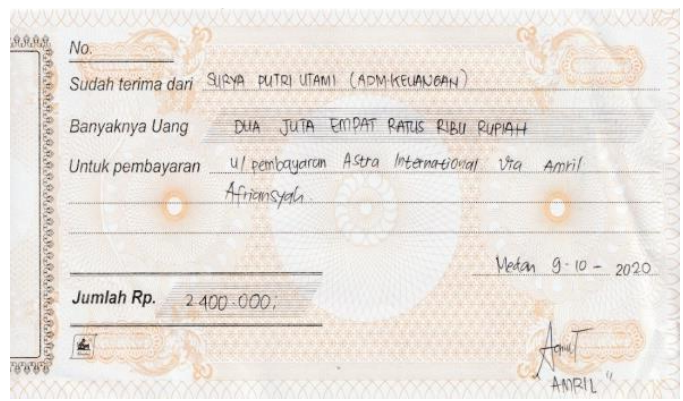

Gambar 1.9 Contoh Kwitansi Bukti Pengeluaran Dana Kas Kecil

Setelah penandatangan dilakukan maka pemegang kas kecil harus melakukan pencatatan secara terperinci pada format yang ada.

\section{Perlakuan Akuntansi Terhadap Dana Kas Kecil PT.Kallista Alam}

Perlakuan akuntansi pada kas kecil merupakan sebuah aturan atau langkah-langkah yang dilakukan dalam proses akuntansi yang meliputi pengakuan,pencatatan, dan penyajian informasi keuangan dalam laporankeuangan perusahaan PT.Kallista Alam.Perlakuan akuntansi berlaku pada saat penerimaan dana kas kecil, pengeluaran dana kas kecil hingga pengisian kembali dana kas kecil pada PT.Kallista Alam Kantor Pusat Medan.Penggunaan metode tidak tetap (Fluctuation Fund System) dan laporan bulanan kas kecil juga telah penulis lakukan dalam pengelolaan kas kecil pada PT.Kallista

\section{Pencatatan Pengeluaran Kas Kecil Yang Terkomputerisasi}

Pencatatan pengeluaran dana kas kecil menggunakan sistem komputerisasi akan lebih efektif dan mengurangi resiko terjadinya kesalahan dalam penjumlahan dana kas kecil. Karena format pengeluaran dana kas kecil telah diisi dengan rumus yang tepat. Penulis telah membuat format pengeluaran dana kas kecil untuk PT.KallistaAlam. 
Table 1.6 Contoh Pencatatan Pengeluaran Dana Kas Kecil yang Terkomputerisasi

\begin{tabular}{|c|c|c|c|c|c|}
\hline \multicolumn{5}{|c|}{ PEMAKAIAN KAS KECIL KEUANGAN TAHUN 2021 Periode Oktober 2020 } \\
\hline $\begin{array}{l}\mathbf{N} \\
\text { o }\end{array}$ & Tanggal & Keterangan & masuk & keluar & saldo \\
\hline & & & & _=Sum(G2 + E3 -F3) \\
\hline 1 & 1-Oct-20 & Terima Dana Dari Pencairan Cek & $50,000,000$ & & $50,000,000$ \\
\hline 2 & 2-Oct-20 & Pengambilan Cash Bpk Direksi & & $5,000,000$ & $45,000,000$ \\
\hline 3 & $2-$ Oct-20 & $\begin{array}{l}\text { Pengambilan Dana u/ Pembelian Sparepart } \\
\text { u/Starda Mega Cabin Tahun 2007 BK1818 } \\
\text { KA dan u/Bibitan }\end{array}$ & & $1,530,000$ & $43,470,000$ \\
\hline 4 & 4-Oct-20 & $\begin{array}{l}\text { Pengambilan Dana u/ Pembelian ATK u/ } \\
\text { Adm.PKS.Timbangan }\end{array}$ & & 831,000 & $42,639,000$ \\
\hline
\end{tabular}

\section{Penggunaan Metode Tidak Tetap Pada Kas Kecil PT.Kallista Alam}

Adapun Fungsi Penjurnalan Kas Kecil ialah untuk membayar pengeluaran perusahaan dengan nominal kecil, kemudian sebagai dana talangan untuk membayar pengeluaran yang bersifat mendadak, sebagai dana langsung untuk jenis pembayaran yang tidak praktis jika menggunakan cek, untuk mempercepat proses pembayaran yang tidak praktis jika menggunakan lampiran keuangan yang perlu ditandatangani direktur terlebih dahulu.

Dibawah ini adalah contoh penjurnalan kas kecil PT.Kallista Alam yang telah di buat sesuai perlakuan akuntansi pad akas kecil yang memiliki penjurnalan untuk setiap transaksi yang terjadi. Ada tiga jurnal yang telah penulis buat yaitu untuk menjurnal pembentukan kas kecil, kemudian jurnal untuk pengeluaran kas kecil, dan jurnal untuk pengisian kembali kas kecil.

Tabel1.7 Jurnal Pembentukan Kas Kecil PT.Kallista Alam

\begin{tabular}{|l|l|l|l|l|}
\hline \multicolumn{5}{|l|}{ Jurnal Pembentukan Kas Kecil } \\
\hline & & & & \\
\hline No. & Tanggal & Nama Akun & Debit & Kredit \\
\hline 1 & 1 -Oct-20 & Kas Kecil & $50,000,000.00$ & \\
\hline & & Kas di Bank & & $50,000,000.00$ \\
\hline & & & & \\
\hline
\end{tabular}

Tabel1.8 Jurnal Pengeluaran Kas Kecil PT.Kallista Alam

\begin{tabular}{|l|r|l|l|l|}
\hline \multicolumn{5}{|c|}{ Jurnal Pengeluaran Kas Kecil } \\
\hline & & & & \\
\hline No. & Tanggal & Nama Akun & Debit & Kredit \\
\hline 1 & $7-$-Oct-20 & Biaya Perjalanan Dinas & $2,500,000.00$ & \\
\hline & & Kas Kecil & & $2,500,000.00$ \\
\hline
\end{tabular}

Tabel1.9 Jurnal Pengisian Kembali Kas Kecil PT.Kallista Alam

\begin{tabular}{|l|l|l|l|r|}
\hline \multicolumn{5}{|l|}{ Jurnal Pengisian Kembali Kas Kecil } \\
\hline & & & & \\
\hline No. & Tanggal & Nama Akun & Debit & Kredit \\
\hline 1 & $10-$ Oct-20 & Kas Kecil & $8,000,000.00$ & \\
\hline & & Kas & & $8,000,000.00$ \\
\hline
\end{tabular}


Metode dana berubah-ubah (Fluctuation Fund System) merupakan suatu sistem pengelolahan dana kas kecil yang saldo rekeningnya tidak tetap dan tergantung pada besar kecilnya pengeluaran yang terjadi untuk periode tertentu, misalnya dalam waktu dua minggu, sebulan dan sebagainya. Pada sistem ini pengeluaran dana kas kecil sama dengan biasa dimana setiap pengeluaran dana kas kecil dicatat atau dijurnal pada tanggal transaksi tersebut. Sistem ini untuk jurnal dana kas kecil dapat berubah-ubah sesuai dengan kebutuhan pemakaian sehingga dapat diperbesar

Dalam sistem dana kas kecil fungsi akuntansi bertanggungjawab atas pencatatan transaksi pembentukan dana kas kecil, pencatatan pengisisan kembali dana kas kecil dalam jurnal pengeluaran kas atau register cek, pencatatan pengeluaran dana kas kecil dalam jurnal pengeluaran dana kas kecil (dalam fluctuation fund system), pembuatan bukti kas keluar yang memberikan otorisasi kepada fungsi kas dalam mengeluarkan cek.

Peneliti telah menjurnal pengeluaran dana kas kecil dari bulan Oktober hingga Desember, dan dapat penulis simpulkan bahwa setelah pengisian kembali dibulan oktober sebesar Rp50.000.000,- ada kenaikan dalam pengisian saldo dibulan November sebesar Rp100.000.000,- jadi saldo kas kecil keuangan berfluktuasi ke jumlah yang lebih besar setelah pengisian kembali dana kas kecil dibulan November. Kenaikan yang terjadi sekitar Rp50.000.000,- dipicu karena adanya pemberitahuan bahwa Direksi akan dinas keluar kota dibulan November, jadi pendanaan biaya sebagian dilakukan melalui dana kas kecil keuangan.

Tabel 1.10 Jurnal Kas Kecil PT.Kallista Alam Periode Oktober 2020

\begin{tabular}{|c|c|c|c|c|c|}
\hline \multicolumn{6}{|c|}{ Metode Dana tidak Tetap } \\
\hline \multicolumn{6}{|c|}{ PT.Kallista Alam } \\
\hline \multicolumn{6}{|c|}{ Jurnal Kas Kecil } \\
\hline \multicolumn{6}{|c|}{ Untuk Periode 31 Oktober 2020} \\
\hline \multicolumn{2}{|c|}{ Tanggal } & Keterangan & Ref & Debit & Kredit \\
\hline & & & & & \\
\hline \multirow[t]{2}{*}{1} & $\begin{array}{c}\text { Oktober } \\
2021\end{array}$ & Kas Kecil & & $50,000,000$ & \\
\hline & & Kas DiBank & & & $50,000,000$ \\
\hline \multirow[t]{13}{*}{31} & $\begin{array}{c}\text { Oktober } \\
2021\end{array}$ & Biaya Pembelian Sparepart & & $1,530,000$ & \\
\hline & & Biaya Pembelian ATK & & 831,000 & \\
\hline & & Biaya Pembelian Alat & & $3,180,000$ & \\
\hline & & Biaya Pembayaran Provident & & $1,193,000$ & \\
\hline & & Biaya Pembelian Alat & & $1,710,000$ & \\
\hline & & Biaya Pembayaran Astra & & $2,400,000$ & \\
\hline & & Biaya Pembelian Egrek & & $3,000,000$ & \\
\hline & & $\begin{array}{l}\text { Biaya Pembayaran Kekurangan } \\
\text { PPH ps1 } 21\end{array}$ & & $1,490,618$ & \\
\hline & & $\begin{array}{l}\text { Biaya Pembayaran } 1 \text { lot upah } \\
\text { Cat }\end{array}$ & & $8,000,000$ & \\
\hline & & Biaya Pembelian Ban & & $6,540,000$ & \\
\hline & & Biaya Pembelian Pompa & & $2,250,000$ & \\
\hline & & Biaya Upah Cabut Rumput & & $3,178,700$ & \\
\hline & & Kas Kecil & & & $34,203,318$ \\
\hline \multirow[t]{6}{*}{31} & $\begin{array}{c}\text { Oktober } \\
2021\end{array}$ & Prive & & $14,000,000$ & \\
\hline & & Kas Kecil & & & $14,000,000$ \\
\hline & & & & & \\
\hline & & & & \multicolumn{2}{|c|}{ Medan, Okt 2021} \\
\hline & & & & \multicolumn{2}{|c|}{ Hormat Saya } \\
\hline & & & & \multicolumn{2}{|c|}{ Surya Putri Utami } \\
\hline
\end{tabular}


Jebma (Jurnal Ekonomi Bisnis, Manajemen dan Akuntansi)

Volume : 1 | Nomor 1 | Maret 2021 | E-ISSN : 2797-7161 |DOI: 10.47709 /jebma.v1n1.971

Tabel 1.11Jurnal Kas Kecil PT.Kallista Alam Periode November 2020

\begin{tabular}{|c|c|c|c|c|c|}
\hline \multicolumn{6}{|c|}{ Metode Dana tidak Tetap } \\
\hline \multicolumn{6}{|c|}{ PT.Kallista Alam } \\
\hline \multicolumn{6}{|c|}{ Jurnal Kas Kecil } \\
\hline \multicolumn{6}{|c|}{ Untuk Periode 30 November 2020} \\
\hline & Tanggal & Keterangan & Ref & Masuk & Keluar \\
\hline & & & & & \\
\hline \multirow[t]{2}{*}{1} & November & Kas DiBank & & 696,682 & \\
\hline & 2020 & Kas Kecil & & & 696,682 \\
\hline \multirow[t]{2}{*}{1} & November & Kas Kecil & & $100,000,000$ & \\
\hline & 2020 & Kas DiBank & & & $100,000,000$ \\
\hline \multirow[t]{18}{*}{30} & November & Biaya Perjalanan Dinas & & $3,500,000$ & \\
\hline & 2020 & Biaya Pembelian Oil Seal & & $5,400,000$ & \\
\hline & & Biay Pembelia Pelet Ikan & & $3,000,000$ & \\
\hline & & Biaya Pembelian Pipa & & $9,450,000$ & \\
\hline & & Biaya Pembelian Kacangan & & $9,700,000$ & \\
\hline & & Biaya Pembelian Sparepart & & 676,900 & \\
\hline & & $\begin{array}{l}\text { Biaya Pembelian Alat dan } \\
\text { Bahan }\end{array}$ & & $4,790,800$ & \\
\hline & & $\begin{array}{l}\text { Biaya Pembelian Alat } \\
\text { Pengecatan }\end{array}$ & & $4,150,000$ & \\
\hline & & Biaya Pembelian Kacangan & & $8,800,700$ & \\
\hline & & Biaya Pembelian Materai & & $4,100,000$ & \\
\hline & & Biaya Upah Cabut Rumput & & $2,750,000$ & \\
\hline & & Biay aPembelian Sparepart & & $8,000,000$ & \\
\hline & & Biaya Upah Cabut Rumput & & $6,540,000$ & \\
\hline & & Biaya Upah Cabut Rumput & & $2,880,000$ & \\
\hline & & Biaya Amprahan Pulsa Subsidi & & $1,223,000$ & \\
\hline & & Biaya Upah Cabut Rumput & & $3,490,000$ & \\
\hline & & $\begin{array}{l}\text { Biaya Kekurangan Gaji } \\
\text { Karyawan }\end{array}$ & & $6,589,382$ & \\
\hline & & Kas Kecil & & & $85,040,782$ \\
\hline \multirow[t]{2}{*}{30} & November & Prive Bpk.Subianto & & $23,220,000$ & \\
\hline & 2020 & Kas Kecil & & & $23,220,000$ \\
\hline \multirow[t]{2}{*}{30} & November & Kas Kecil & & $8,000,000$ & \\
\hline & 2020 & Kas DiBank & & & $8,000,000$ \\
\hline
\end{tabular}


Jebma (Jurnal Ekonomi Bisnis, Manajemen dan Akuntansi)

Volume : 1 | Nomor 1 | Maret 2021 | E-ISSN : 2797-7161 |DOI: 10.47709 /jebma.v1n1.971

Tabel 1.12 Jurnal Kas Kecil PT.Kallista Alam Periode Desember2020

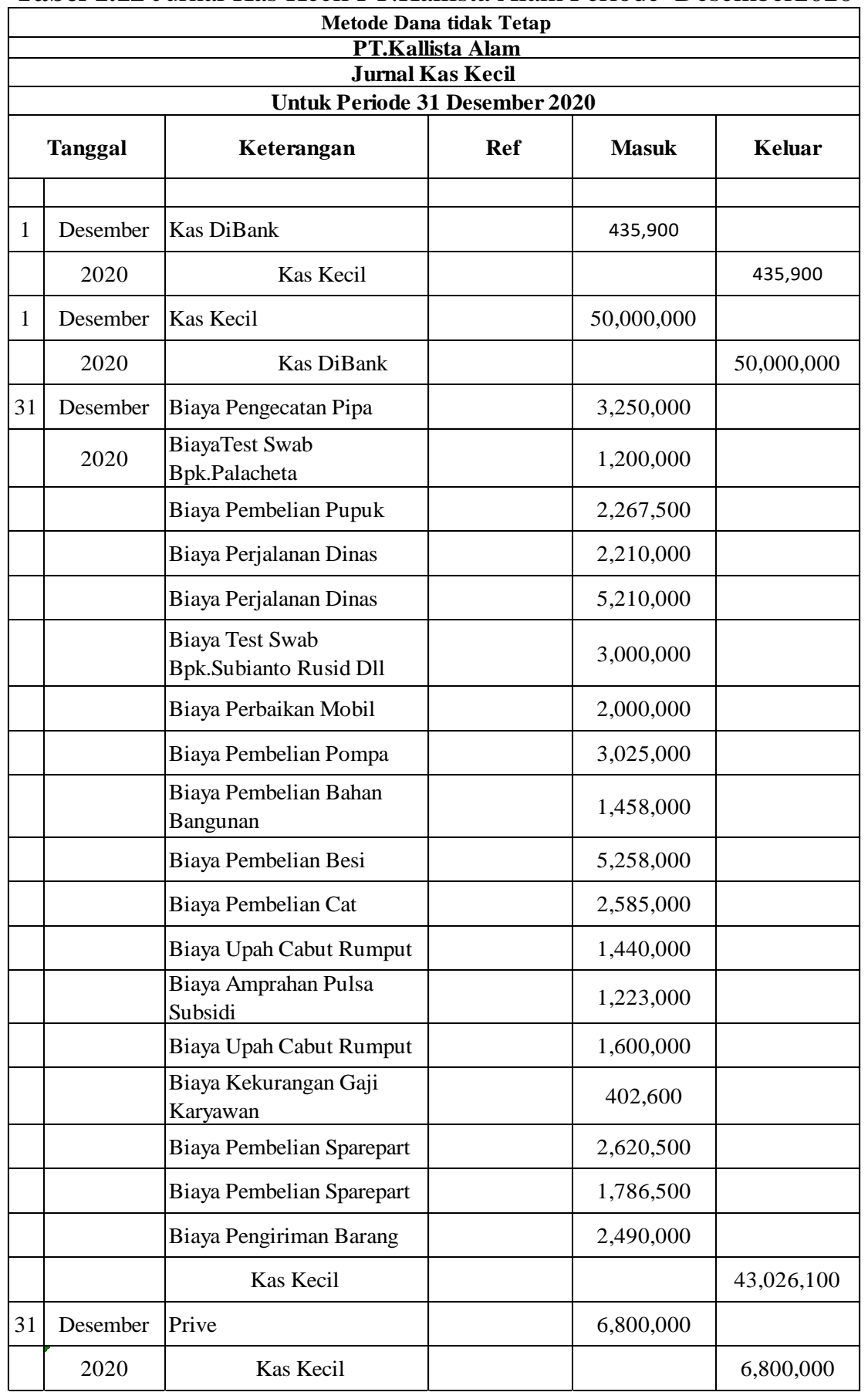

\section{Pertanggung Jawaban Kas Kecil PT.Kalllista Alam Kantor Medan.}

Hasil pengelolaan data kas kecil PT. Kallista Alam Medan dengan menetapkan saldo minimum kas kecil sebesar Rp 500.000,- sehingga apabila kas kecil menunjukan angka mendekati Rp 500.000,- maka kas kecil harus diisi kembali agar tidak terjadi kekosongan dana kas kecil. Berikut adalah laporan kas kecil periode Oktober hingga Desember 2020 yang sudah diolah. 
Tabel 1.13Laporan Kas Kecil PT.Kallista Alam Periode Oktober2020 dan Laporan Kas Kecil PT.Kallista Alam Periode November2020

\begin{tabular}{|c|c|c|c|c|c|c|}
\hline & & & F.KALLISTA A & & & \\
\hline & & LAPOK & IN KAS KECIL & petty cash) & & \\
\hline & & & de 31 ОКтОВ & 2020 & & \\
\hline & & & & & & \\
\hline No & Tanggal & Nama Akun & Keterangan & Debet & Kredit & saldo \\
\hline 1 & 1-Oct-20 & Pengisian Uang Kas & \begin{tabular}{|l} 
No.Cek IG \\
872616
\end{tabular} & $50,000,000$ & & $50,000,000$ \\
\hline 2 & 2-Oct-20 & Prive Bpk.Subianto & Via Pak Erwah & & $5,000,000$ & $45,000,000$ \\
\hline 3 & 2-Oct-20 & Biaya Pembelian Alat & Untuk Bibitan & & $1,530,000$ & $43,470,000$ \\
\hline 4 & 4-Oct-20 & Biaya Pembelian Atk & Untu PKS & & 831,000 & $42,639,000$ \\
\hline 5 & 5-Oct-20 & Biaya Pembelian Alat & $\begin{array}{l}\text { Untuk POS } \\
\text { Security }\end{array}$ & & $3,180,000$ & $39,459,000$ \\
\hline 6 & 6-Oct-20 & $\begin{array}{l}\text { Biaya Kekurangan Pembayaran } \\
\text { CVFB }\end{array}$ & Via Agustiawan & & $1,193,000$ & $38,266,000$ \\
\hline 7 & 7-Oct-20 & Biaya Pembelian Alat & Via Agustiawan & & $1,710,000$ & $36,556,000$ \\
\hline 8 & 8-Oct-20 & Biaya Astra & $\begin{array}{l}\text { Via Amril } \\
\text { Afriansyah }\end{array}$ & & $2,400,000$ & $34,156,000$ \\
\hline 9 & 9-Oct-20 & Biaya Egrek & Via Pamela Sari & & $3,000,000$ & $31,156,000$ \\
\hline 10 & 13-Oct-20 & Biaya Kekurangan Pajak & Kasir & & $1,490,618$ & $29,665,382$ \\
\hline 11 & $15-$ Oct-20 & Biaya Upah Cat & 1 Lot & & $8,000,000$ & $21,665,382$ \\
\hline 12 & 17-Oct-20 & Biaya Pembelian Ban & Via Agustiawan & & $6,540,000$ & $15,125,382$ \\
\hline 13 & $18-$ Oct-20 & Biaya Upah Cabut Rumput & Via Pak Erwah & & $2,250,000$ & $12,875,382$ \\
\hline 14 & 23-Oct-20 & Biaya Pembelian Pompa & Untuk Masjid & & $3,178,700$ & $9,696,682$ \\
\hline 15 & $25-$ Oct-20 & Prive Bpk.Subianto & Via Pak Erwah & & 4,000,000 & $5,696,682$ \\
\hline 16 & 29-Oct-20 & Prive Bpk.Subianto & Via Pak Erwah & & $5,000,000$ & 696,682 \\
\hline & & & & & & 696,682 \\
\hline
\end{tabular}

\begin{tabular}{|c|c|c|c|c|c|c|}
\hline \multicolumn{7}{|c|}{ PT.KALLISTA ALAM } \\
\hline \multicolumn{7}{|c|}{ LAPORAN KAS KECIL (petty cash) } \\
\hline \multicolumn{7}{|c|}{ Periode 30 November 2020} \\
\hline No & & & & & & \\
\hline & Tanggal & Keterangan & masuk & masuk & keluar & saldo \\
\hline & & & & & & 696,682 \\
\hline 1 & 1-Nov-20 & Pengisian Uang Kas & $\begin{array}{l}\text { No Cek IG } \\
873591\end{array}$ & $100,000,000$ & & $100,696,682$ \\
\hline 2 & 1-Nov-20 & Biaya Perjalanan Dinas & Kasir & & $3,500,000$ & $97,196,682$ \\
\hline 3 & 3-Nov-20 & Biaya Pembelian Alat & \begin{tabular}{|l|} 
Via Pak Narto \\
\end{tabular} & & $5,400,000$ & $91,796,682$ \\
\hline 4 & 4-Nov-20 & Prive Bpk.Subianto & \begin{tabular}{|l|} 
Via Pak Erwah \\
\end{tabular} & & $2,408,000$ & $89,388,682$ \\
\hline 5 & 5-Nov-20 & Biaya Pelet Ikan & \begin{tabular}{|l|} 
Via Pak Erwah \\
\end{tabular} & & $3,000,000$ & $86,388,682$ \\
\hline 6 & 5-Nov-20 & Biaya Pipa & \begin{tabular}{|l|} 
Via Agustiawan \\
\end{tabular} & & $9,450,000$ & $76,938,682$ \\
\hline 7 & 7-Nov-20 & Biaya Kacangan & \begin{tabular}{|l|} 
Via Agustiawan \\
\end{tabular} & & $9,700,000$ & $67,238,682$ \\
\hline 8 & 8-Nov-20 & Biaya Sparepart & \begin{tabular}{|l|} 
Via Agustiawan \\
\end{tabular} & & 676,900 & $66,561,782$ \\
\hline 9 & 9-Nov-20 & Biaya Pembelian Alat & \begin{tabular}{|l|} 
Via Agustiawan \\
\end{tabular} & & $4,790,800$ & $61,770,982$ \\
\hline 10 & 10-Nov-20 & Biaya Pembelian Alat & \begin{tabular}{|l|} 
Via Agustiawan \\
\end{tabular} & & $4,150,000$ & $57,620,982$ \\
\hline 15 & 15-Nov-20 & Prive Bpk.Subianto & \begin{tabular}{|l|} 
Via Pak Erwah \\
\end{tabular} & & $8,000,000$ & $49,620,982$ \\
\hline 12 & 12-Nov-20 & Biaya Kacangan & $\begin{array}{r}\text { Via Amril } \\
\text { Afriansyah }\end{array}$ & & $8,800,700$ & $40,820,282$ \\
\hline 13 & 14-Nov-20 & Biaya Materai & \begin{tabular}{|l|} 
Via Pak Erwah \\
\end{tabular} & & $4,100,000$ & $36,720,282$ \\
\hline 14 & 14-Nov-20 & Biaya Upah Cabut Rumput & \begin{tabular}{|l|} 
Via Pak Erwah \\
\end{tabular} & & $2,750,000$ & $33,970,282$ \\
\hline 15 & 15-Nov-20 & Pengisian Uang Kas & \begin{tabular}{|l|} 
Via Pak Erwah \\
\end{tabular} & $8,000,000$ & & $41,970,282$ \\
\hline 16 & 16-Nov-20 & Biaya Sparept & \begin{tabular}{|l|} 
Via Agustiawan \\
\end{tabular} & & $8,000,000$ & $33,970,282$ \\
\hline 17 & 17-Nov-20 & Biaya Upah Cabut Rumput & \begin{tabular}{|l|} 
Via Pak Erwah \\
\end{tabular} & & $6,544,000$ & $27,430,282$ \\
\hline 18 & 18-Nov-20 & Prive Bpk.Subianto & \begin{tabular}{|l|} 
Via Pak Erwah \\
\end{tabular} & & $5,012,000$ & $22,418,282$ \\
\hline 15 & 19-Dec-20 & Biaya Upah Cabut Rumput & Kasir & & $2,880,000$ & $19,538,282$ \\
\hline 16 & 21-Dec-20 & Biaya Subsidi Pulsa & \begin{tabular}{|l|} 
Via Pak Erwah \\
\end{tabular} & & $1,223,000$ & $18,315,282$ \\
\hline 17 & 26-Dec-20 & Biaya Upah Cabut Rumput & \begin{tabular}{|l|} 
Via Pak Erwah \\
\end{tabular} & & $3,490,000$ & $14,825,282$ \\
\hline 18 & 28-Dec-20 & Prive Bpk.Subianto & \begin{tabular}{|l|} 
Via Pak Erwah \\
\end{tabular} & & $7,800,000$ & $7,025,282$ \\
\hline 19 & 29-Dec-20 & \begin{tabular}{|l} 
Biaya Kekurangan Gaji \\
Karyawan
\end{tabular} & Via Pak Erwah & & $6,589,382$ & 435,900 \\
\hline & & & & & & 435,900 \\
\hline & & & & & & \\
\hline & & Saldo Kas Masuk Noy'202 & $\operatorname{Rp} 108696682$. & & & \\
\hline & & Saldo Kas Keluar Nov'202 & Rp 108.260.782,- & & & \\
\hline
\end{tabular}

\section{Kesimpulan}

Berdasarkan pembahasan di atas maka penulis dapat menarik kesimpulan berhubungan dengan pengelolahan dana kas kecil. Hal ini dimaksudkan agar perusahaan dapat dengan baik mengelolah dana kas kecils esuai dengan standar akuntansi yang berlaku pada umumnya. Apabila perusahaan dapat memperlakukan dana kas kecil dengan baik dan benar, maka diharapkan dapat menjadi awal bertambah baiknya keadaan perusahaan terutama dibidang keuangan. Kesimpulan ialah sebagai berikut 1). PT. Kallista Alam Kantor Medan tidak menentukan batas saldo minimum kas kecil. Apabila PT.Kallista Alam menentukan batasan saldo minimum tidak akan terjadi kekosongan kas kecil sehingga tidak menganggu kegiatan operasional perusahaan. 2). PT. Kallista Alam Kantor Medan juga tidak melakukan pemisahaan dalam penggunaan kas kecil. Apabila dengan dilakukannya pemisahaan beban dalam pengelolahannya, jumlah kas kecil tidak begitu besar. Sesuai dengan pengertian kas kecil yang bertujuan untuk membiaya pengeluaran yang jumlahnya kecil.

\section{Referensi}

Suwadjono, “Analisis Akuntansi Kas Kecil Pada PT.Awfa Smart Media” D, vol.2, pp.25-26, Maret. 2019 Sumarsan, "Akuntansi Dasar Dan Aplikasi Dalam Bisinis Versi IFRS", Jurnal ilmiah Akuntansil. vol.1, pp. 14-15, Mei. 2017

Paul Gradi, “Analisis Kas Kecil Pada PT.Industri Sandang Nusantara Patal Tohpati”, Jurnal Pendidikan Ekonomul. vol.2, pp. 36, April. 2016

Mulyadi, Sistem Akuntansi Edisi Empat. Jakarta :Salemba, 2016 pp.45

Mulyadi, Sistem Akuntansi Edisi Empat. Jakarta :Salemba, 2016 pp.52

Rizal Effendi," Prinsip-Prinsip Akuntansi ”, Ed.Jakarta, Indonesia (SalembaEmpat),2016

Agoes.S, Petunjuk Praktis Pemeriksaan Akuntansi oleh Kantor Akuntan Publik. Jakarta: Salemba.2016 
Jebma (Jurnal Ekonomi Bisnis, Manajemen dan Akuntansi)

Volume : 1 | Nomor 1 | Maret 2021 | E-ISSN : 2797-7161 |DOI: 10.47709 /jebma.v1n1.971

Samryn, Pengantar Akuntansi-Metode Akuntansi Untuk Elemen.Laporan Keuangan Diperkaya Dengan Perspektif IFRS dan Perbankan. Ed: $1^{\text {st }}$.Erlangga.Yogyakarta.2015

Mulyadi, Sistem Akuntansi Edisi Empat. Jakarta :Salemba, 2016 pp.62-63

Mulyadi, Sistem Akuntansi Edisi Empat. Jakarta :Salemba, 2016 pp.63

Soemarsono.Pengantar Akuntansi .Jakarta: Salemba Empat.2019 pp52-53

Suranti, Dwi.'Perlakuan Akuntansi Kas Kecil". Journal of Applied Accounting and Taxation, Vol1.No.1 pp: 21.-24.2016

Rudianto. "Sistem Akuntansi Dana Kas Kecil Pada PT.Jasa Marga (Persero) Tbk, Cabang Balmera Medan", Vol.2, no.2 pp.12-13, Agustus

Sandi,"Pengendalian Kas Kecil Pada Anugrah CV". Journal Ilmiah Akuntansi,Vol.2, no.3, pp.23-24

Sandi,"Pengendalian Kas Kecil Pada Anugrah CV". Journal Ilmiah Akuntansi, Vol.2, no.3, pp.29-31

Mulyadi, Sistem Akuntansi Edisi Empat. Jakarta :Salemba, 2016

Risal Effendi,"'Analisis Akuntansi Kas Kecil Menggunakan Metode Dana Tidak Tetap UD.Maju

Permai".Jurnal akuntansi dan Bisnis, Vol.4,Mei 2015

Mulyadi, Sistem Akuntansi Edisi Empat. Jakarta :Salemba, 2016 pp.91

Mulyadi, Sistem Akuntansi Edisi Empat. Jakarta :Salemba, 2016 pp-91-92

Mulyadi, Sistem Akuntansi Edisi Empat. Jakarta :Salemba, 2016 pp.97-98 